\title{
Impact of extraction methods upon light absorbance of natural organic dyes for dye sensitized solar cells application
}

\author{
Barness Chirazo Mphande*, Alexander Pogrebnoi \\ Dept. of Materials Science and Engineering, The Nelson Mandela African Institution of Science and Technology, Arusha, Tanzania
}

\section{Email address:}

bcmphande@gmail.com (B. C. Mphande), alexander.pogrebnoi@nm-aist.ac.tz (A. Pogrebnoi)

\section{To cite this article:}

Barness Chirazo Mphande, Alexander Pogrebnoi. Impact of Extraction Methods upon Light Absorbance of Natural Organic Dyes for Dye Sensitized Solar Cells Application. Journal of Energy and Natural Resources. Vol. 3, No. 3, 2014, pp. 38-45.

doi: 10.11648/j.jenr.20140303.13

\begin{abstract}
Aqueous extraction, cold ethanol, and Soxhlet hot ethanol extraction methods were used to study the general trend in performance of dyes as sensitisers for dye sensitized solar cells (DSSC) from different plants based on optical absorbance, and consequently light harvesting efficiency (LHE). Spathodea campanulata, Thevetia peruviana, Hibiscus sabdariffa, Delonix regia and Acalypha wilkesiana 'Haleakala' were used in this study. From the UV/Visible spectrophotometer with the recorded absorption measurements in the range between $300-700 \mathrm{~nm}$, the cold ethanol and Soxhlet hot ethanol extracts exhibited LHE between $80-100 \%$ over $400 \sim 550 \mathrm{~nm}$ of visible range, and 40 - 99\% for water extracts dyes between $400-700 \mathrm{~nm}$. Ethanol extract of Acalypha wilkesiana 'Haleakala' had the highest LHE and a widely spread optical spectrum between $400-700 \mathrm{~nm}$; it was earmarked as a potential sensitizer candidate for DSSC. The phytochemical screening was applied to detect the presence of anthocyanins, quinones, cuomarines and others in the extracts. Based on the phytochemical screening, there was no appreciable impact of the extraction methods on the presence of the organic compounds relative to individual samples; and also the optical absorption showed that no extraction method was found consistently better than the other in all extracts.
\end{abstract}

Keywords: Dye Sensitized Solar Cell, Extraction Method, Optical Absorbance, Light-Harvesting-Efficiency, Natural Organic Dye, Phytochemical Screening

\section{Introduction}

Dye sensitized solar cell (DSSC) is a solar cell that employs dyes to absorb light from the sun and convert it into electrical energy. DSSC, pioneered by Michael Grätzel and Brian O'Regan in 1991 [1, 2] are a third generation solar cell technologies that is attracting huge attention in the scientific research. Dyes are classified as synthetic and natural organic dyes of which the latter are the area of focus. Natural organic dyes are extracted from plants using various extraction methods. There are three most commonly used extraction methods, namely: Soxhlet hot ethanol, cold ethanol, and heating in water. Each extraction method is said to have an effect on the performance of the DSSC. Several studies have been done on extractions where one or two methods have been used to determine which one gives better results. Trial-and-error has been the criterion for selection of the method. There is no report available that shows the effect of these methods of extraction upon the performance of the solar cells for individual plant species and if those effects also apply over a range of plants. It is hypothesized that there is a strong correlation between the method of extraction and optical absorbance or light harvesting efficiency (LHE) of the dye. The LHE is indicative of the incident photon-to-current conversion efficiency (IPCE) of the DSSC.

The main research objective was to investigate the effects of extraction methods of natural dyes upon LHE for DSSC applications for which five plant species were studied. Through the expected trend between the method of extraction and optical absorbance, the findings will contribute to a pool of knowledge for applications and 
further research in DSSC technologies.

\section{Materials and Methods}

\subsection{Preparation}

Five dyes were prepared from the flowers of Spathodea campanulata, Thevetia peruviana, Hibiscus sabdariffa, Delonix regia and leaves of Acalypha wilkesiana 'Haleakala'. Both flowers and leaves were air dried for some time until they became invariant in weight. Using the lab blender (WARING COMMERCIAL, Torrington Connecticut - USA), each specimen was ground to fine particles. Aqueous, cold ethanol and Soxhlet hot ethanol were the three extraction methods that were studied. Using the analytical scale (OHAUS Corporation - USA, made in China), $12.5 \mathrm{~g}$ of each sample and $125 \mathrm{ml}$ of the solvent were measured. Distilled water was the solvent for aqueous extraction, and ethanol 96\% v/v (AVONCHEM Ltd, Wellington House, Macclesfield Cheshire SKII 6PJ) for cold ethanol and Soxhlet hot ethanol extraction methods. For aqueous extraction method, each sample was heated at six different temperatures $\left(40-90{ }^{\circ} \mathrm{C}\right.$ with $10{ }^{\circ} \mathrm{C}$ step $)$ for 30 - 50 min after which Whatman No. 41 filter paper was used to filter out solid particles. The optimum extraction temperature of each sample was determined based on the optical absorbance at uniform acidity $(\mathrm{pH} \mathrm{3})$. It was this sample at optimum temperature that was used for comparison with other extraction methods. The ground Hibiscus sabdariffa formed a jelly-like stuff on either heating or soaking in cold water. The uncrushed dry flowers were, instead, heated in distilled water for $15 \mathrm{~min}$ and filtered. For cold ethanol method, each sample was soaked in ethanol for 1 week, after which the filtrates were obtained. Using the Soxhlet method, the filtrates for each sample were also obtained after 5 to 6 hours of extraction process. The extracts were kept in the refrigerator at $4{ }^{\circ} \mathrm{C}$ until they were required for characterization.

\subsection{Characterization}

Each sample underwent the optical absorbance test using the UV/Vis spectrophotometer (SQ 2800 Single beam spectrophotometer, UNICO - USA); and LHE for each sample was calculated using the following formula [3]

$$
\left(1-10^{-\mathrm{A}(\lambda)}\right) \times 100
$$

where $A(\lambda)$ is the absorbance at a specific wavelength.

To obtain the absorbance curve, the scanning for each sample was repeated for at least three times in the wavelength range between $300-700 \mathrm{~nm}$, and the respective averaged curves were considered hereafter.

\subsection{Phytochemical Screening}

A qualitative screening was carried out to detect the presence of phytochemicals in plant extracts. Flavonoids, quinones, cuomarines, anthocyanins, anthraquinones, and carotenoids were the chemical compounds that are of practical relevance in DSSC applications. The phytochemical tests were performed on the liquid extracts using standard methods (Table 1).

Table 1. Phytochemical screening protocols

\begin{tabular}{|c|c|c|c|c|c|}
\hline Phytochemicals & \multicolumn{2}{|c|}{ Test } & \multicolumn{2}{|c|}{ Indicator } & Reference \\
\hline Phenol & \multicolumn{2}{|r|}{$1 \mathrm{ml}$ extract $+2 \mathrm{ml}$ of distilled water $+10 \% \mathrm{FeCl}_{3}$. } & \multicolumn{2}{|c|}{ Blue or green colour. } & \multirow{4}{*}[4]{} \\
\hline \multirow{3}{*}{ Anthocyanin } & a) & Extract $+10 \%$ sodium hydroxide. & a) & Blue colour. & \\
\hline & a) & Extract + conc. sulphuric acid. & b) & Yellowish orange. & \\
\hline & b) & Small amount of extract $+2 \mathrm{~N} \mathrm{NaOH}$. & c) & Blue-green colour. & \\
\hline Quinones & \multicolumn{2}{|c|}{$1 \mathrm{ml}$ of extract $+1 \mathrm{ml}$ conc. $\mathrm{H}_{2} \mathrm{SO}_{4}$. } & \multicolumn{2}{|c|}{ Red colour. } & \\
\hline Cuomarines & \multicolumn{2}{|c|}{$1 \mathrm{ml}$ of $10 \% \mathrm{NaOH}+1 \mathrm{ml}$ of extract. } & \multicolumn{2}{|c|}{ Yellow colour. } & \\
\hline Anthraquinones & \multicolumn{2}{|c|}{$1 \mathrm{ml}$ extract + few drops of $10 \% \mathrm{NH}_{3}$. } & \multicolumn{2}{|c|}{ Pink colour precipitate. } & {$[5]$} \\
\hline Flavonoids & \multicolumn{2}{|r|}{$\begin{array}{l}1 \mathrm{ml} \text { extract }+ \text { few drops of } \mathrm{NaOH} \\
1 \mathrm{ml} \text { extract }+ \text { few drops of } \mathrm{NaOH}+\text { few drops of dilute acid. }\end{array}$} & \multicolumn{2}{|c|}{$\begin{array}{l}\text { An intense yellow colour, } \\
\text { Colourless appearance. }\end{array}$} & {$[4]$} \\
\hline Carotenoids & \multicolumn{2}{|c|}{ Extract + chloroform + drops of conc. $\mathrm{H}_{2} \mathrm{SO}_{4}$. } & \multicolumn{2}{|c|}{ Deep-blue colored layers. } & {$[6]$} \\
\hline
\end{tabular}

\section{Results and Discussion}

\subsection{Dyes Spectral-Responses on the Extraction Methods}

Many extraction methods for natural dyes from plants exist, but the most commonly used methods for DSSC applications are Soxhlet, aqueous method, and cold ethanol method. It is a common practice to use trial-and-error method to determine the appropriate extraction method for a particular plant(s) species. This study was aimed at establishing the common trend of these methods relative to optical absorbance for different plant species.

For aqueous extraction method, the optimum temperatures for each type of extracts are as follows: Acalypha wilkesiana 'Haleakala' - $70{ }^{\circ} \mathrm{C}$, Hibiscus sabdariffa $-50{ }^{\circ} \mathrm{C}$, Thevetia peruviana $-60^{\circ} \mathrm{C}$, Spathodea campanulata $-60{ }^{\circ} \mathrm{C}$, and Delonix regia $-50{ }^{\circ} \mathrm{C}$.

Figure 1 depicts the results of the three extraction methods for five samples, and a set of observations were made. Within the near-ultraviolet region (NUV, approx. 300 
- $400 \mathrm{~nm})$, there are two occurrences common to all. All dyes have nearly the same absorbance except for Spathodea campanulata that has conspicuously shown lower absorbance for the water extract (Figure 1 (d)) and the water extract for Acalypha wilkesiana 'Haleakala' also drops further to 2.0 a.u. at $300 \mathrm{~nm}$. But also, all plant species have the similar absorption spectra in the NUV region: their absorbance fall between 2.5 and 3.5 a.u. (Figures 1 and 2).

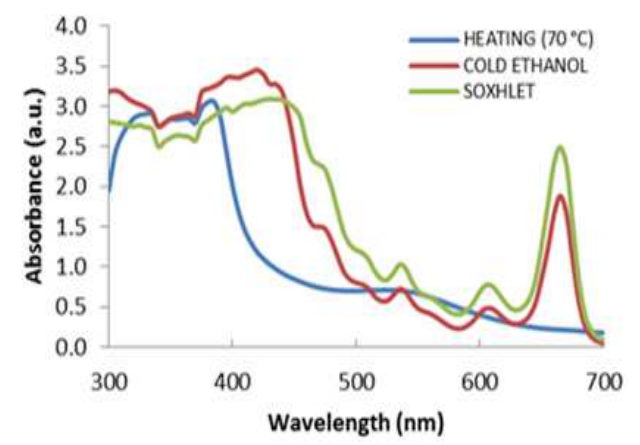

(a)

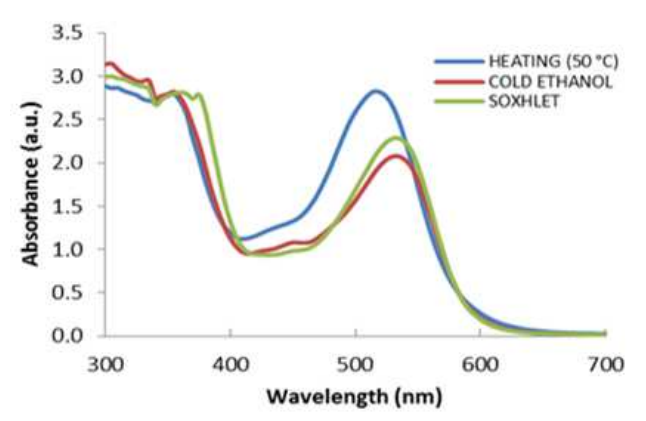

(b)

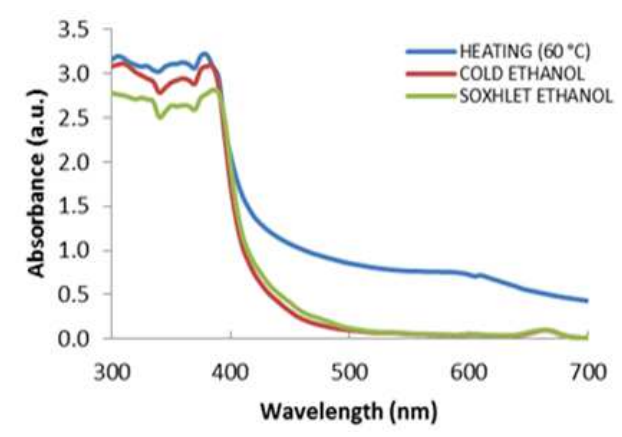

(c)

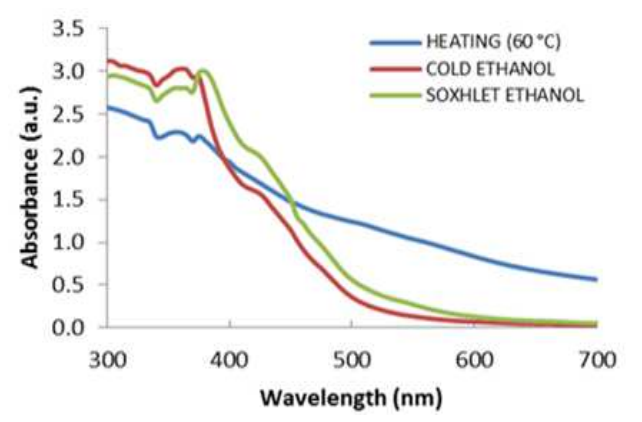

(d)

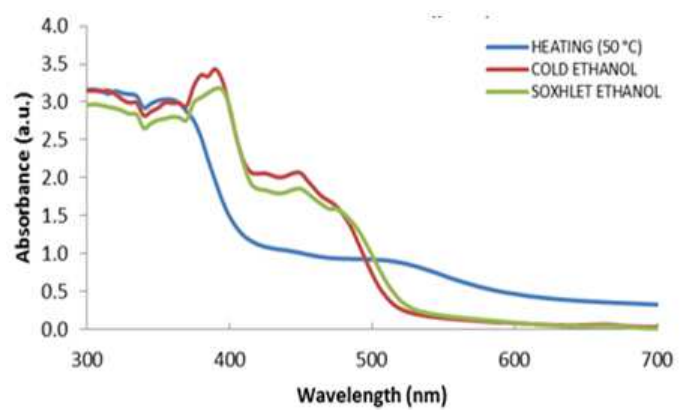

(e)

Figure 1. Comparison of extraction methods for individual species, all at pH 3; (a) Acalypha wilkesiana 'Haleakala'; (b) Hibiscus sabdariffa; (c) Thevetia peruviana; (d) Spathodea campanulata; (e) Delonix regia

This may be due to similar chemical composition of the constituents of the plants that are responsible for absorbance in the NUV range. In the visible region that ranges from $400-700 \mathrm{~nm}$ [7], the absorption peaks for both Soxhlet and cold ethanol extracts occur at the same wavelengths, and there is negligible difference (Figures 1(a), (b), (d) and (e)) or no difference at all (Figure 1(c)) in magnitudes of absorption. In a study by Boyo and co-workers [8] who used these two methods in dye sensitized solar cell with dyes extracted from Lawsonia inermis stem bark, this marginal difference was also reported. Extracts obtained by heating in water have not shown a predictable trend of absorbance as compared to ethanol extracts. For instance, the absorbance for water extract from Acalypha wilkesiana 'Haleakala' is low between $400-500 \mathrm{~nm}$; also it is closely equal to that of Soxhlet and cold ethanol extracts between $500-650 \mathrm{~nm}$ (Figure 1(a)); for Thevetia peruviana and Spathodea campanulata, the absorbance of water extracts is higher than those of Soxhlet and cold ethanol extracts between $400-700 \mathrm{~nm}$ and $450-700 \mathrm{~nm}$ respectively. Similarly, Delonix regia water extract has shown lower absorbance between $400-500 \mathrm{~nm}$, but higher thereafter to $700 \mathrm{~nm}$. Besides, water extracts have shown to have wider and nearly consistent spectra between $400-700 \mathrm{~nm}$ wavelengths.

All the plant samples were studied for their responses relative to the extraction method. Figure 2 shows the spectra of the five samples for cold ethanol and aqueous extracts. Since the absorption profiles of Soxhlet and cold ethanol spectra are similar (Figure 1), Figure 2(a) is as well representative of Soxhlet extracts spectra. Hibiscus sabdariffa was found to have the maximum absorption peak at $535 \mathrm{~nm}$ for both Soxhlet and cold ethanol methods. In various studies, it has been reported to have the maximum absorbance peak between 500 and $550 \mathrm{~nm}$ [9-11] which is in agreement with the finding in this study. It was hereby used as a bench mark. In our study, the dye from Delonix regia was found to have an absorption maximum peak at $450 \mathrm{~nm}$ for cold ethanol and Soxhlet extracts, and an elevation at $506 \mathrm{~nm}$ in water extract (Figures 1(e), 2 (a) and (b)). Delonix regia was also used before in DSSC by 
Kimpa et al. [12]. The dye was extracted by cold ethanol, and the absorption spectrum was found to be between 350 and $500 \mathrm{~nm}$ whose peak was at $415 \mathrm{~nm}$. In another study by Adje et al. [13], the dye was extracted by heating in water; the phytochemical analysis showed that the dye had three different anthocyanins, namely; cyanidin 3-O-glucoside, cyanidin 3-O-rutinoside, and pelargonidin 3-O-rutinoside whose absorbance were at 516, 516 and $506 \mathrm{~nm}$ respectively, and this concurs with the finding about absorption peaks of Delonix regia by Godibo [14] who researched on Amaranthus caudatus, Bougainvillea spectabilis, Delonix regia, Nerium oleanders, and Spathodea campanulata. These results are in support of our findings for Delonix regia and Spathodea campanulata.

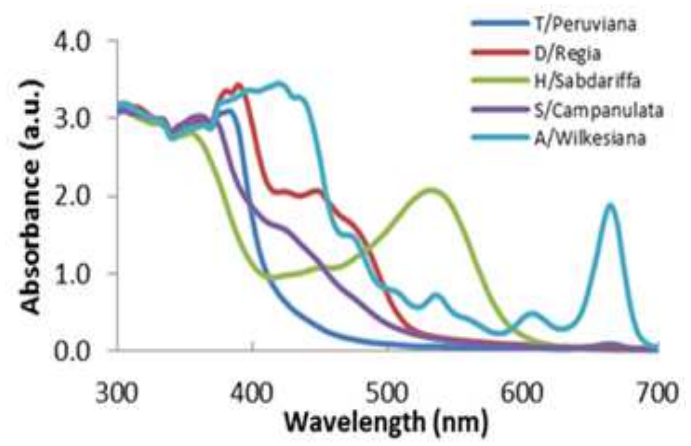

(a)

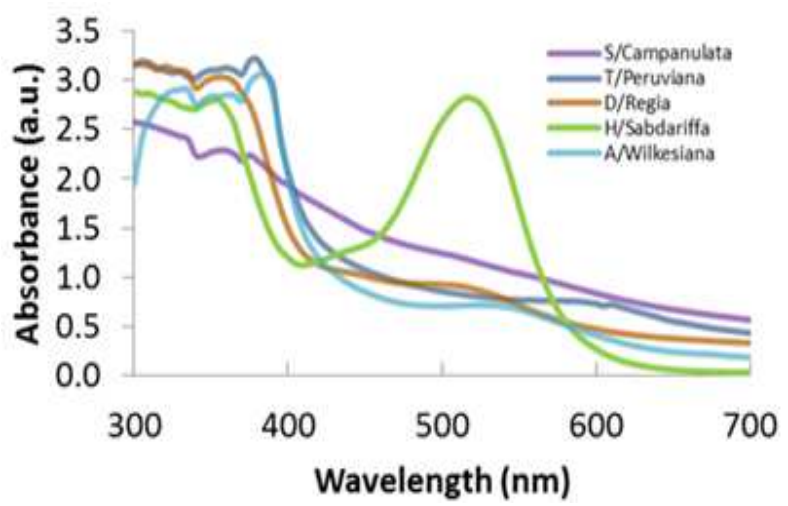

(b)

Figure 2. Spectra of extracts of the five samples: (a) cold ethanol; (b) Aqueous (water).

Spathodea campanulata was found to have no definite maximum absorption peak within the visible range for the water extract, and stretched over a wider area in the electromagnetic spectrum between $400-700 \mathrm{~nm}$. For cold ethanol and Soxhlet extracts (Figure 1 (d)), there was a narrow area of absorption (i.e. between 400 and $450 \mathrm{~nm}$ ) if 1.0 a.u. and $400 \mathrm{~nm}$ (Figure 3 ) would be arbitrarily taken as the minimum values of the curve for effective optical absorbance and wavelength respectively under consideration in the spectra above. The maximum peak was deemed to be at $400 \mathrm{~nm}$ for cold ethanol and Soxhlet hot ethanol methods. The results are also in full agreement with the previous study by Godibo [14]. In that study, acidified water $(0.1 \mathrm{M} \mathrm{HCl})$ was used as one of the extracting solvents. From the absorbance spectrum, it was also observed that Spathodea campanulata had no obvious maximum absorption peak [14]. In our study, both Spathodea campanulata and Delonix regia were also used to compare their performance relative to different extraction methods based on optical absorbance for their consideration in DSSC suitability and application.

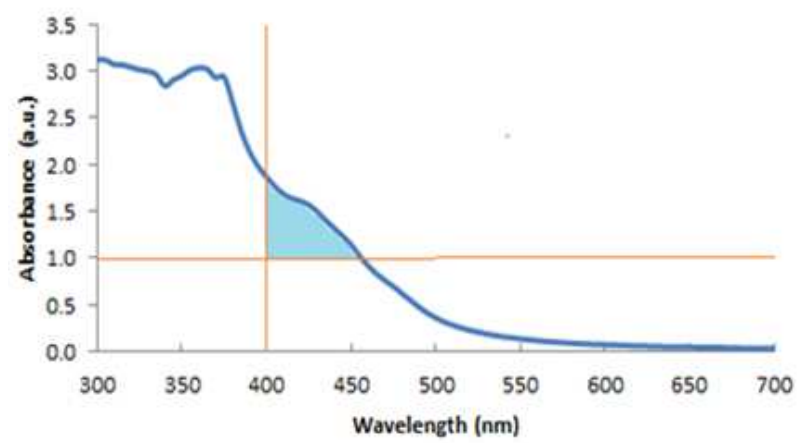

Figure 3. An illustration of the effective area of optical absorption under the curve within the visible range for the sample.

Thevetia peruviana and Acalypha wilkesiana 'Haleakala' have not been studied before for the application in DSSCs. Thevetia peruviana, in Figure 1 (c), shows that it has a very narrow absorption area $(\sim 400-450 \mathrm{~nm})$ and negligible absorbance beyond $500 \mathrm{~nm}$ except for a minute shoulder at $663 \mathrm{~nm}$ regarding cold ethanol and Soxhlet methods in the visible range of the electromagnetic spectrum. The shoulder is indicative of the presence of chlorophyll a [14]. However, there was a considerable absorbance in aqueous extract and over a wider range between 400 and $700 \mathrm{~nm}$ for Thevetia peruviana.

Acalypha wilkesiana 'Haleakala' showed several peaks of absorbance over the visible range for cold ethanol and Soxhlet methods. The maximum absorption peak is at 420 $\mathrm{nm}$ with a corresponding peak at $663 \mathrm{~nm}$ which are indicative of the presence of chlorophyll a, but also a peak at $440 \mathrm{~nm}$ with the corresponding peak at $605 \mathrm{~nm}$ show the presence of chlorophyll b [14]. The two chlorophylls complement each other in absorbance of sunlight. The peaks at 515 and $535 \mathrm{~nm}$ are indicative of the presence of anthocyanins which may be responsible for its coppery appearance. Anthocyanins absorb sunlight more within this region. For this sample, cold ethanol and Soxhlet extracts have consistently shown higher absorbance than water extracts (Figure 1(a)).

In Figure 1, it is seen that Soxhlet extracts absorb slightly better than cold ethanol in the visible range, but the difference between the two is negligible. The advantage of Soxhlet hot ethanol method is that it has a short extraction time ( $3-6 \mathrm{hrs})$ as opposed to $12 \mathrm{hrs}-1$ week for cold ethanol method, though it has a likelihood of the dye not performing long in DSSC due to possible thermal decomposition of the target compounds [15] caused by high extraction temperatures $\left(>78^{\circ} \mathrm{C}\right.$, boiling point of ethanol). 
On the other hand, the absorption trend for water extracts is closely similar for all plant species used (Figure 2 (b)) except for Hibiscus sabdariffa. The absorbance at $400 \mathrm{~nm}$ is high but drops almost uniformly towards $700 \mathrm{~nm}$. The level of absorbance on the greater part of absorption spectra in the visible range is rather relatively low considering the suitability of water extracts for DSSC applications. The low absorbance contributes to the lower IPCE in DSSC as compared to ethanol extracts. However, water extracts have shown to be better in absorbance than other ethanol extract for some plant species, Thevetia peruviana and Spathodea campanulata for instance (Figure 1(c) and (d)). Prior tests are therefore necessary for water extracts. In this study, Acalypha wilkesiana 'Haleakala' proved to be the potential candidate as a sensitizer in DSSC. Its absorption capability covers the visible range from $400-700 \mathrm{~nm}$, and its absorbance pattern is similar to that of Tectona grandis (Teak) species whose IPCE was $37 \%$ in a study by Kushwaha and co-workers [16].

\subsection{Light Harvesting Efficiencies}

Besides the optical absorption spectra, LHEs were also calculated for the visible region ranging from $400-700 \mathrm{~nm}$ considering the fact that their absorbance was almost equal in the NUV region except for Spathodea campanulata's water extract (Figure 1(d)) whose absorbance is slightly lower.

Table 2. Light harvesting efficiencies

\begin{tabular}{|c|c|c|c|c|c|c|c|}
\hline Sample & $\begin{array}{l}\text { Extraction } \\
\text { method }\end{array}$ & Wavelength, $\lambda$ (nm) & LHE (\%) & Sample & $\begin{array}{l}\text { Extraction } \\
\text { method }\end{array}$ & Wavelength, $\lambda(\mathrm{nm})$ & LHE (\%) \\
\hline \multirow{6}{*}{$\begin{array}{l}\text { Hibiscus } \\
\text { sabdariffa }\end{array}$} & \multirow{2}{*}{$\mathrm{CE}$} & 400 & 92.5 & \multirow{7}{*}{$\begin{array}{l}\text { Thevetia } \\
\text { peruviana }\end{array}$} & \multirow{2}{*}{$\mathrm{CE}$} & 400 & 98.9 \\
\hline & & 535 & 99.2 & & & 450 & 61.1 \\
\hline & \multirow{2}{*}{ SHE } & 400 & 95.3 & & \multirow{2}{*}{ SHE } & 400 & 98.9 \\
\hline & & 535 & 99.5 & & & 450 & 61.1 \\
\hline & \multirow{3}{*}{ Aq. } & 400 & 94.0 & & \multirow{3}{*}{ Aq. } & 400 & 98.9 \\
\hline & & 520 & 99.9 & & & 500 & 85.9 \\
\hline \multirow{11}{*}{$\begin{array}{l}\text { Delonix } \\
\text { regia }\end{array}$} & & 400 & 99.9 & & & 600 & 81.3 \\
\hline & \multirow[t]{2}{*}{$\mathrm{CE}$} & 445 & 99.1 & \multirow{18}{*}{$\begin{array}{l}\text { Acalypha } \\
\text { wilkesiana } \\
\text { 'Haleakala' }\end{array}$} & \multirow{6}{*}{$\mathrm{CE}$} & 400 & 100.0 \\
\hline & & 500 & 81.5 & & & 420 & 100.0 \\
\hline & \multirow{3}{*}{ SHE } & 400 & 99.9 & & & 470 & 96.7 \\
\hline & & 445 & 98.6 & & & 500 & 84.0 \\
\hline & & 500 & 84.0 & & & 535 & 81.2 \\
\hline & \multirow{4}{*}{ Aq. } & 400 & 96.8 & & & 665 & 98.7 \\
\hline & & 445 & 90.6 & & \multirow{6}{*}{ SHE } & 400 & 99.9 \\
\hline & & 500 & 89.6 & & & 420 & 99.9 \\
\hline & & 535 & 84.5 & & & 470 & 99.5 \\
\hline & \multirow{3}{*}{$\mathrm{CE}$} & 400 & 98.6 & & & 500 & 93.9 \\
\hline \multirow{8}{*}{$\begin{array}{l}\text { Spathodea } \\
\text { campanulata }\end{array}$} & & 425 & 97.3 & & & 535 & 89.7 \\
\hline & & 500 & 72.5 & & & 665 & 99.7 \\
\hline & \multirow{4}{*}{ SHE } & 400 & 99.6 & & \multirow{6}{*}{ Aq. } & 400 & 99.0 \\
\hline & & 425 & 99.2 & & & 500 & 84.3 \\
\hline & & 500 & 72.5 & & & 535 & 77.5 \\
\hline & & 400 & 96.6 & & & & \\
\hline & \multirow[t]{2}{*}{ Aq. } & 500 & 94.2 & & & 665 & 39.7 \\
\hline & & 600 & 86.4 & & & & \\
\hline
\end{tabular}

Key: $\mathrm{CE}=$ cold ethanol; $\mathrm{SHE}=$ Soxhlet hot ethanol; Aq. $=$ aqueous

Table 2 depicts the LHEs for each sample with regard to extraction method at specific wavelengths $(\lambda)$ at which absorption peaks were seen. From the Table, the LHEs show clearly that there is no any remarkable difference between cold ethanol and Soxhlet extraction methods based on optical absorbance of the dyes since the values are almost equal for each sample. This, therefore, means that the two methods can be used interchangeably. However, caution has to be taken considering thermal degradation of the dyes due to hot ethanol in Soxhlet extraction method [8, 11]. Extraction by use of ethanol is not universally applicable for all species as evidenced by LHE for Thevetia peruviana as well as the spectra in Figure 1 (c). Acalypha wilkesiana 'Haleakala' showed both from the spectra and LHE its better absorption capability.

\subsection{Phytochemical Screening}

Frequently, dyes have been used as crude extracts (extracts without isolation) for DSSC applications. There are a large number of plant constituents available in the crude extracts that contribute to absorbance and consequently the impact on IPCE of the DSSC. It was for this reason that the phytochemical screening was conducted to investigate the impact of the extraction methods on the presence of such organic compounds relative to each extraction method. Phytochemicals such as quinones, flavonoids, anthraquinones, anthocyanins, and cuomarines were the target compounds because they have very important roles to play in DSSC. A brief overview of their functions in plants and importance in DSSC has been 
discussed in the following paragraphs.

Phenols $\left(\mathrm{C}_{6} \mathrm{H}_{6} \mathrm{O}\right)$ are a class of chemical compounds consisting of a hydroxyl group (-OH) bonded directly to an aromatic hydrocarbon group. Depending on the number of phenol units in the molecule, phenolic compounds are classified as simple phenols or polyphenols. Phenolic compounds are ubiquitous groups of secondary metabolites found throughout the plant kingdom [4]. They form a diverse group that includes the widely distributed hydroxybenzoic and hydroxycinnamic acids [17]. By virtue of having hydroxyl and carboxylic groups, plant phenolics make good metal chelators [18] - the most needful requirement in DSSC, besides playing key roles as major red, blue and purple pigments, as well as UV sunscreen.

Flavonoids comprise a large group of polyphenol compounds having a benzo- $\gamma$-pyrone structure and are ubiquitously present in plants; they serve as ultraviolet filters. Ultraviolet radiation is classified into UV-A (320 $390 \mathrm{~nm})$, UV-B $(280-320 \mathrm{~nm})$, and UV-C (<280 nm) [19], UV-B radiation is the most damaging class against which the flavonoids shield by absorption [20].

Quinones occur as biological pigments that are available in plants. Various colour pigments such as chloranil and lawsone are quinone derivatives. Alizarin (1,2-dihydroxy-9,10-anthraquinone) extracted from the madder plant, for instance, was the first natural dye to be synthesized from coal tar [21]. Currently, there is an ongoing research study about the possible application of quinone (Alizarin and Lawsone) as a photosensitizer in DSSC that commenced in 2012 by Sreekala and Achuthan [22]. Quinones produce yellow, red or brown coloration in plants [23], and are very important in conversion of light into chemical energy [23]. Quinones in general are expected to absorb light between 420 - $430 \mathrm{~nm}$ [24].

Anthraquinone $\left(\mathrm{C}_{14} \mathrm{H}_{8} \mathrm{O}_{2}\right)$ is a polycyclic aromatic hydrocarbon containing two opposite carbonyl groups $(\mathrm{C}=\mathrm{O})$ at 9,10 position, a subgroup of quinones. It occurs in plants, fungi, lichens, and insects as a parent material for colouring of yellow, orange, red, red-brown, or violet [25]. Anthraquinones and their derivatives are also used as photosensitizers in photovoltaic cells $[26,27]$. Chaoyan Li et al. [27] designed three anthraquinone dyes with carboxylic acid as anchoring group as sensitizers for DSSCs. They found out that anthraquinone dyes have very low performance on DSSC applications despite having broad and intense absorption spectra in the visible region up to $800 \mathrm{~nm}$ in the near infra-red (NIR) region.

Anthocyanins are a class of flavonoids responsible for the attractive bright red, purple, violet, and blue colours of most fruits, vegetables, flowers, leaves, roots and other plant storage organs [11]. The basic C6-C3-C6 anthocyanin structure is the source of diverse colours. Besides carotenoids and chlorophylls, anthocyanins in flavonoids are also the most important group of plant pigments [23], and the most applied dyes in DSSCs because of their excellent chelation capability, generally, to $\mathrm{TiO}_{2}$ and ability to convert light energy to electrical energy. Their spectral absorbance lies within the range of $460-550 \mathrm{~nm}$ in the electromagnetic spectrum with the reported maximum absorbance at $520 \mathrm{~nm}$ [28].

Coumarin $\left(\mathrm{C}_{9} \mathrm{H}_{6} \mathrm{O}_{2}\right)$ is a colourless natural substance that is found in many plants that is a fragrant organic chemical compound in the benzopyrone class. It is used as a sensitizer $[29,30]$ in DSSC. The dyes are developed and applied as coumarin derivatives to improve IPCE [31]. As coumarin derivatives, the photon-to-current conversion efficiency of $7.4 \%$ has been achieved [32].

Carotenoids $\left(\mathrm{C}_{40} \mathrm{H}_{56}\right.$ - the general molecular structure $)$ comprise a large group of lipid soluble pigments that exhibit yellow, orange, and red colours, and are found in all kinds of plants. Other colours such as green, orange, or blue are exhibited when carotenoids are bound to proteins [6]. Carotenoids are involved in several aspects of photosynthesis, notably light absorption and energy transfer to the reaction centers (RC) complex and protection of the photosynthetic apparatus from damage by strong illumination [33]. Attempts have been made to apply carotenoids in DSSC. Yamazaki et al. [34] fabricated a DSSC using crocetin and crocin as photosensitizers from which crocetin performed the best with an IPCE of $0.56 \%$. The absorption maximum depends on the number of conjugated bonds; it is around $450 \mathrm{~nm}$ for $\beta$-carotene [33].

Table 3. Results of the phytochemical preliminary screening of the crude plant extracts

\begin{tabular}{|c|c|c|c|c|c|c|c|c|c|c|c|c|c|c|c|}
\hline \multirow[t]{2}{*}{ Phytochemical } & \multicolumn{3}{|c|}{$\begin{array}{l}\text { Acalypha wilkesiana } \\
\text { 'Haleakala' }\end{array}$} & \multicolumn{3}{|c|}{ Hibiscus sabdariffa } & \multicolumn{3}{|c|}{ Thevetia peruviana } & \multicolumn{3}{|c|}{ Delonix regia } & \multicolumn{3}{|c|}{ Spathodea campanulata } \\
\hline & SHE & CE & $\mathbf{A q}$ & SHE & $\mathbf{C E}$ & $\mathbf{A q}$ & SHE & $\mathbf{C E}$ & $\mathbf{A q}$ & SHE & $\mathbf{C E}$ & $\mathbf{A q}$ & SHE & $\mathbf{C E}$ & $\mathbf{A q}$ \\
\hline Phenols & ++ & + & +++ & + & + & ++ & + & + & + & + & + & + & + & + & + \\
\hline Flavonoids & ++ & + & + & + & + & + & + & + & + & + & + & + & + & + & + \\
\hline Quinones & - & - & + & + & + & + & + & + & + & ++ & ++ & ++ & + & + & + \\
\hline Anthocyanins & + & + & + & ++ & ++ & +++ & - & - & - & + & + & + & + & + & + \\
\hline Anthraquinones & - & - & - & - & - & - & - & - & - & - & - & - & - & - & - \\
\hline Cuomarines & + & + & + & + & + & + & + & + & - & - & - & - & + & + & - \\
\hline Carotenoids & + & + & - & + & + & - & ++ & ++ & - & + & + & - & + & + & - \\
\hline
\end{tabular}


From the qualitative testing of the phytochemical constituents of all plant samples (Table 3), a number of observations were made. As per sample, Acalypha wilkesiana 'Haleakala' showed the absence of quinones in both ethanol extracts as opposed to water extract. This could have been the reason why ethanol extracts appeared green instead of reddish appearance as it was with water extract. By colour intensity, Hibiscus sabdariffa showed the presence of higher concentration of anthocyanins than all other samples, and even more in water extracts than in ethanol extracts. Higher light absorbance as shown in Figures 1(b), 2(a) and 2(b) are supported by this result; and better IPCE is expected from this sample. Thevetia peruviana, on the other hand, indicated to have a high concentration of carotenoids in ethanol extracts than all other samples, but anthocyanins were not present in all of these extracts' samples. The absence of anthocyanins is confirmed by the absorbance curves in Figure 1 (c) and Figure 2 (b) that do not show any peak or elevation in the region within $460-550 \mathrm{~nm}$ where anthocyanins absorb. The rather high absorbance for water extracts in this area may be attributed to chlorophyll as depicted by a small peak at around $620 \mathrm{~nm}$. Despite having high concentration of carotenoids in ethanol extract, the absorbance is very low. This indicates that carotenoids are not good enough in absorbing light. The yellow colour of the extracts may be attributed to quinones, cuomarines and other constituents that may not have been detected. Delonix regia does not show the presence of cuomarines in all of its extracts, but Thevetia peruviana and Spathodea campanulata have them in ethanol extracts. In general, carotenoids are present in ethanol extracts of all samples except in water extracts. Carotenoids are generally insoluble in water [35], with the exception of crocin [4].

As per extraction method, the trend of the presence of phytochemicals in all plant extracts is similar in both cold ethanol and Soxhlet hot ethanol extracts. The reason may be due to the same extraction solvent used in both the extraction methods. This implies that performance in both optical absorbance (LHE) and IPCE are expected to be similar as Figure 1 ascertains the results. Anthraquinones were conspicuously not present in any of the plant extracts regardless of the extraction method. Flavonoids and phenols were found in every sample being the ubiquitous plant constituents [4]. Generally the impact of extraction methods on the phytochemical presence was slight with the exception of Thevetia peruviana.

\section{Conclusion}

The three methods of extracting natural organic dyes (i.e. cold ethanol, Soxhlet hot ethanol, and aqueous methods) have been applied and analysed. Based on light absorption of extracts, it has been found that there is a slight difference between cold ethanol and Soxhlet hot ethanol. These two methods can be used interchangeably though consideration has to be made with regard to other factors such as thermal degradation, time and ease of extraction, and availability of the apparatus. On the other hand, the trend of absorbance of light for all water extracts used was closely similar except for Hibiscus sabdariffa. Compared to ethanol extracts, the area of effective absorbance of light for water extracts is, however, very narrow. Though the area of absorption stretches over the whole visible range, the magnitude of absorption is not high enough for practical applications in DSSC for commercial purposes. The phytochemical screening has shown that there is no appreciable impact of the extraction methods on the presence of organic compounds relative to individual samples. From the findings, no extraction method of the three is outstandingly better than the other in all plant samples. However, the difference in absorbance between water extracts and ethanol extracts may be due to differences in concentrations and nature of phytochemicals.

\section{Acknowledgements}

The authors would like to thank The Nelson Mandela African Institution of Science and Technology (NM-AIST) for the sponsorship. We are also pleased to acknowledge the valuable assistance and service by the School of Life Science and BioEngineering at NM-AIST.

\section{References}

[1] Hedbor, S. and Klar, L., Plant Extract Sensitised Nanoporous Titanium Dioxide Thin Film Photoelectrochemical Cells. Examensarbete. 2005, p. 20

[2] O'Regan, B. and Grätzel, M., A Low-Cost, High Efficiency Solar Cell Based on Dye-Sensitized Colloidal TiO 2 Film. Nature. 353(6346), 1991, p. 737-740.

[3] Jasim, K.E., Dye Sensitized Solar Cells - Working Principles, Challenges and Opportunities, in Solar Cells Dye-Sensitized Devices, P.L.A. Kosyachenko, Editor 2011, InTech: Kingdom of Bahrain. p. 35.

[4] Harborne, J.B., Phytochemical Methods: A guide to modern techniques of plant analysis. 1973, New York: Chapman and Hall. 279.

[5] Kapoor, L.D., Singh, A., Kapoor, S.L., and Srivastava, S.N., Survey of Indian plants for saponins, alkaloids and flavonoids. I. Lloydia. 32(3), 1969, p. 297-304.

[6] Saluja, M.P., Kumar, R., and Agarwal, A., Advanced Natural Products. Carotenoids, ed. S. Rastogi. Vol. 1. 2008, Raj Printers, Meerut: Satyendra Rastogi Mitra (KRISHNA Prakashan Media (P) Ltd. 362.

[7] Jones, A.Z. The Visible Light Spectrum. [cited 201425 May]; Available from: http://physics.about.com/od/lightoptics/a/vislightspec.htm.

[8] Boyo, A.O., Boyo, H.O., Abudusalam, I.T., and Adeola, S., Dye-sensitised Nanocrystalline Titania Solar Cell using Laali Stem Bark (Lawsonia inermis). Transnational Journal of Science and Technology. 2(4 ), 2012, p. 13. 
[9] Okonkwo and Nnaemeka, T.J., Hibiscus Sabdariffa Anthocyanidins: A Potential Two-Colour End-Point Indicator in Acid-Base and Complexometric Titrations. International Journal of Pharmaceutical Sciences Review and Research. 4(3), 2010, p. 123-128.

[10] Selim, K.A., Khalil, K.E., Abdel-Bary, M.S., and Abdel-Azeim, N.A., Extraction, Encapsulation and Utilization of Red Pigments from Roselle (Hibiscus sabdariffa L.) as Natural Food Colourants, in 5th Alex. Conference of food \& dairy science and technology 2008, Alexandria Journal of Food Science and Technology: Alexandria, Egypt. p. 7 - 20.

[11] Wongcharee, K., Meeyoo, V., and Chavadej, S., Dye-sensitized solar cell using natural dyes extracted from rosella and blue pea flowers. Solar Energy Materials and Solar Cells. 91(7), 2007, p. 566-571.

[12] Kimpa, M.I., Momoh, M., Isah, K.U., Yahya, H.N., and Ndamitso, M.M., Photoelectric Characterization of Dye Sensitized Solar Cells Using Natural Dye from Pawpaw Leaf and Flame Tree Flower as Sensitizers. Materials Sciences and Applications. 3(5), 2012, p. 281-286.

[13] Adje, F., Lozano, Y.F., Meudec, E., Lozano, P., Adima, A., Agbo N'zi, G., and Gaydou, E.M., Anthocyanin Characterization of Pilot Plant Water Extracts of Delonix regia Flowers. Molecules. (13), 2008, p. 7.

[14] Godibo, D.J., Screening of Natural Dyes for Use in Dye Sensitized Solar Cells, in Materials Science2012, Addis Ababa: Addis Ababa, Ethiopia. p. 70.

[15] Handa, S.S., Khanuja, S.P.S., Longo, G., and Rakesh, D.D., Extraction Technologies for Medicinal and Aromatic Plants. Decoction and Hot Continuous Extraction Techniques, ed. S. Tandon and S. Rane. 2008, Triesta, Italy: International Centre for Science and technology. 266.

[16] Kushwaha, R., Srivastava, P., and Bahadur, L., Natural Pigments from Plants Used as Sensitizers for $\mathrm{TiO}_{2}$ Based Dye-Sensitized Solar Cells. Journal of Energy. 2013, 2013, p. 8

[17] Ray Sahelian, M.D. Phenolic Compounds and Acids, benefit of phenols. 2014 [cited 201420 May]; Available from: http://www.raysahelian.com/phenolic.html.

[18] Lattanzio, V., Lattanzio, V.M.T., and Cardinali, A., Role of phenolics in the resistance mechanisms of plants against fungal pathogens and insects, in Phytochemistry: Advances in Research, F. Imperato, Editor. 2006, Research Signpost: Fort P.O., Trivandrum-695 023, Kerala, India. p. 23-67

[19] Burger, J. and Edwards, G.E., Photosynthetic Efficiency, and Photodamage by UV and Visible Radiation, in Red versus Green Leaf Coleus Varieties. Plant Cell Physiol. 37(3), 1996, p. 395-399

[20] Kootstra, A., Protection from UV-B-induced DNA damage by flavonoids. Plant Molecular Biology. 26(2), 1994, p. 771-774.

[21] Wikimedia. Quinone. 2014 [cited 201416 May]; Available from: http://en.wikipedia.org/wiki/Quinone\#Dyes.

[22] Sreekala, C.O. and Achuthan, K. Natural Dyes as Efficient
Candidate for Enhancing the Photovoltaic Properties of Dye Sensitized Solar Cells 2012 [cited 201412 May]; Available from: http://biotech.amrita.edu/research/30.html.

[23] Delgado-Vargas, F., Jiménez, A.R., and Paredes-López, O., Natural Pigments: Carotenoids, Anthocyanins, and Betalains - Characteristics, Biosynthesis, Processing, and Stability. Critical Reviews in Food Science and Nutrition. 40(3), 2000, p. 173-289.

[24] Reusch, W. Visible and Ultraviolet Spectroscopy. 2013 [cited $2014 \quad 20 \quad$ May]; $\quad$ Available from: http://www2.chemistry.msu.edu/faculty/reusch/virttxtjml/sp ectrpy/uv-vis/spectrum.htm.

[25] Chemicalland21. Anthraquinone. [cited 201414 May]; Available from: http://www.chemicalland21.com/specialtychem/finechem/A NTHRAQUINONE.htm.

[26] Lehr, F., Anthraquinone dyes as photosensitizers in photovoltaic cells, 2009, Google Patents.

[27] Li, C., Yang, X., Chen, R., Pan, J., Tian, H., Zhu, H., Wang, X., Hagfeldt, A., and Sun, L., Anthraquinone dyes as photosensitizers for dye-sensitized solar cells. Solar Energy Materials and Solar Cells. 91(19), 2007, p. 1863-1871.

[28] Anthocyanin Absorption Spectrum. [cited 201415 May, 2014]; Available from: http://cellbiologyolm.stevegallik.org/anthocyanin/page17.

[29] Edward W. Castner, J., Kennedy, D., and Cave, R.J., Solvent as Electron Donor: Donor/Acceptor Electronic Coupling Is a Dynamical Variable. J. Phys. Chem. A 104, 2000, p. 2869-2885.

[30] Faber, C., Duchemin, I., Deutsch, T., and Blase, X., Many-body Green's function study of coumarins for dye-sensitized solar cells. Physical Review B: Condens. Matter Mater. 86 (155315), 2012, p. 1-7.

[31] Hara, K., Sayama, K., Ohga, Y., Shinpo, A., Sugab, S., and Arakawa, H., A coumarin-derivative dye sensitized nanocrystalline $\mathrm{TiO}_{2}$ solar cell having a high solar-energy conversion efficiency up to $5.6 \%$. The Royal Society of Chemistry. 2001, p. 569-570.

[32] Hara, K., Wang, Z.-S., Sato, T., Furube, A., Katoh, R., Sugihara, H., Dan-oh, Y., Kasada, C., Shinpo, A., and Suga, S., Oligothiophene-Containing Coumarin Dyes for Efficient Dye-Sensitized Solar Cells. J. Phys. Chem. B 109, 2005, p. 15476-15482.

[33] Mimuro, M. and Katoh, T., Carotenoids in photosynthesis: absorption, transfer and dissipation of light energy. Pure \& Appl. Chern. 63(1), 1991, p. 123-130.

[34] Yamazaki, E., Murayama, M., Nishikawa, N., Hashimoto, N., Shoyama, M., and Kurita, O., Utilization of natural carotenoids as photosensitizers for dye-sensitized solar cells. Solar Energy. 81(4), 2007, p. 512-516.

[35] Rahiman, R., Ali, M.A.M., and Ab-Rahman, M.S., Carotenoids Concentration Detection Investigation: A Review of Current Status and Future Trend. International Journal of Bioscience, Biochemistry and Bioinformatics. 3(5), 2013, p. 466-472. 